\title{
FEMALE SCAUP INCUBATES RING-BILLED GULL EGGS
}

KEVIN J. MCCORMICK and JACQUES SIROIS, Canadian Wildlife Service, Yellowknife, Northwest Territories. X1A 2N5

During June 1986, we conducted a survey of larid breeding sites along the North Arm of Great Slave Lake, Northwest Territories. ${ }^{1}$ On June 24, we inspected a large Ring-billed Gull colony (132 nests) (UTM location: NV 7950 4500) which also included four scaup nests. After flushing one female scaup, we discovered that the nest contained nine scaup eggs plus two Ringbilled Gull eggs. One gull egg was fully pipped (end of egg shell was completely removed) and a still-wet chick had vacated the other egg. The scaup eggs showed no signs of impending hatch.

The duck that we flushed was probably a Lesser Scaup, ${ }^{8}$ Trauger and Bromley indicated that Greater Scaup are more abundant on the West Mirage Islands; approximately $60 \mathrm{~km}$ southeast of this site. ${ }^{5}$ However, Sirois and Seddon reported only one Greater Scaup nest among 26 Lesser Scaup nests located at 22 larid breeding sites on near-shore islands along the North Arm. ${ }^{3}$ Clearly, Lesser Scaup are most common on the mainland adjacent to the North Arm.

The scenario resulting in the scaup and gull clutches becoming mixed is not entirely clear. The nest was a shallow depression surrounded by large, overhanging tufts of grass - a typical Lesser Scaup nest. ${ }^{2}$ However, available evidence suggests that the nest was initiated by a Ring-billed Gull and probably also incubated, in part, by her. Lesser Scaup hens lay at a rate of one egg per day with a possible one-day interval during clutch deposition; incubation begins after the clutch has been completed. ${ }^{2}$ Therefore, if the scaup hen did all the incubating, the scaup clutch would

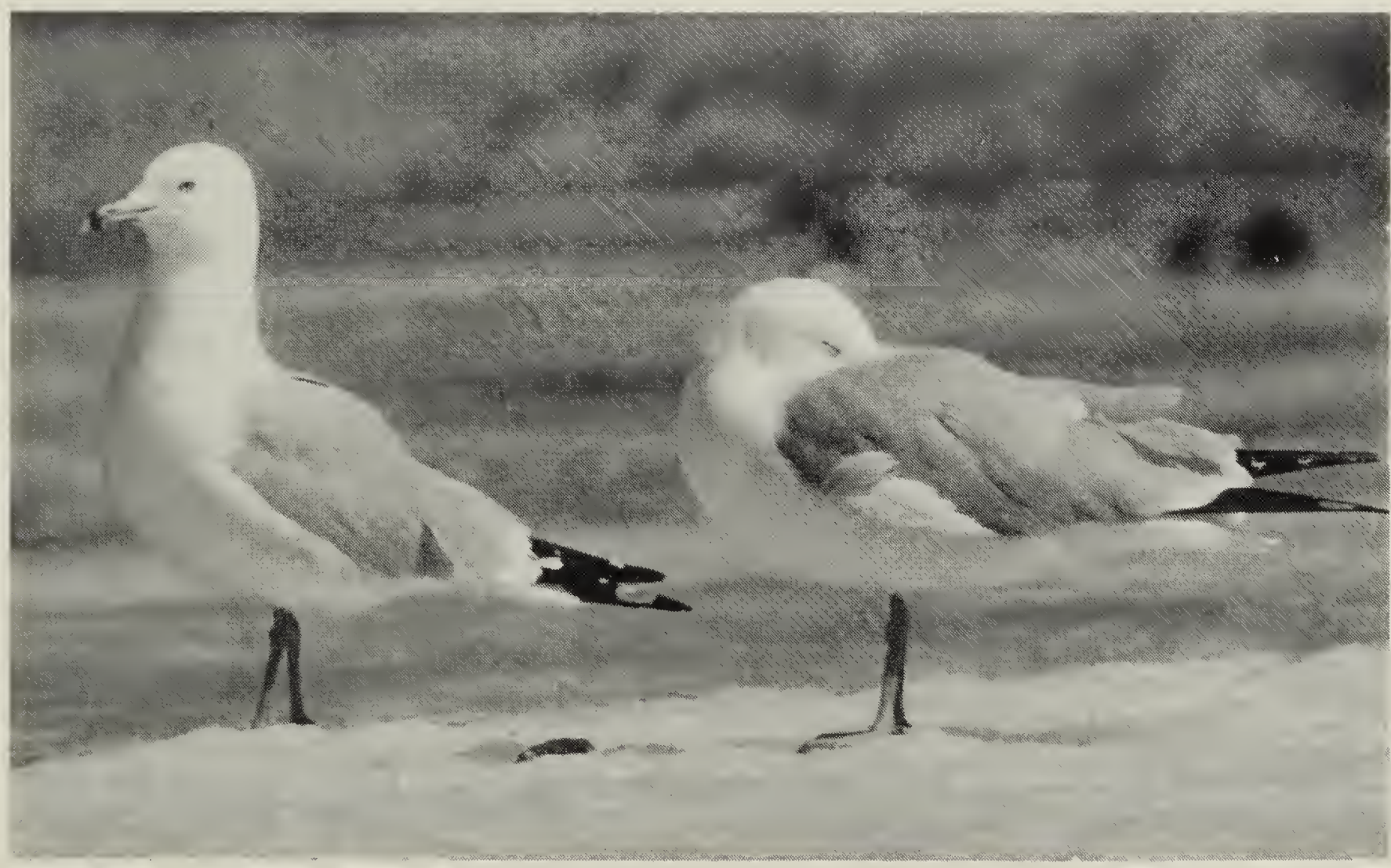


have been initiated 32-37 days previously (nine days for laying the scaup eggs plus 23-28 days for incubating the gull eggs).?

This would suggest that the scaup clutch was initiated between 18-25 May - an unlikely situation given the nesting chronology on the nearby mainland. Lesser scaup do not begin laying before 1 June and most have not initiated before the second week of June (J. Hines pers. comm.). ${ }^{4}$ Accordingly, even the earliest females do not begin incubating before 10 June.

Approximately $28 \%$ of the other Ringbilled Gull nests contained at least one chick, indicating that these two gull eggs were laid in synchrony with the rest of the colony. Such synchrony suggests that the gull eggs were incubated initially by a Ring-billed Gull and later taken over by the scaup. Vermeer reported that Lesser Scaup were attracted to larid colonies only after the larids had started nesting. ${ }^{6}$ In this case, it appears that the Lesser Scaup displaced a Ring-billed Gull from her nest or took possession of a nest that had been abandoned. The fate of the gull chicks or scaup eggs is unknown.

1. McCORMICK, K. J. and J. SIROIS. 1988. Larid breeding sites on the North Arm of Great Slave Lake, Northwest Territories: 1986. Tech. Rept. Ser. No. 30, Can. Wildl.
Serv., Yellowknife. 44 pp.

2. PALMER, R. S. 1976. Handbook of North American birds. Vol. 3. Yale University Press, New Haven and London. 560 pp.

3. SIROIS, J. and L. SEDDON. 1990. Status of larid breeding sites between Frank Channel and Yellowknife Bay, and other observations of larids in the North Arm of Great Slave Lake: 1988. Tech. Rept. Ser. No. 90, Can. Wildl. Serv., Yellowknife. 44 pp.

4. TRAUGER, D.L. 1971. Population ecology of Lesser Scaup (Aythya affinis) in subarctic taiga. Unpubl. PhD Thesis, Iowa State Univ., Ames. 118 pp.

5. TRAUGER, D. L. and R. BROMLEY. 1976. Additional bird observations on the West Mirage Islands, Great Slave Lake, Northwest Territories. Can. Field-Nat. 90:114-122.

6. VERMEER, K. 1968. Ecological aspects of ducks nesting in high densities among larids. Wils. Bull. 80:78-83.

7. 1970. Breeding biology of California and Ring-billed Gulls: a study of ecological adaptation to an island habitat. Rept. Ser. No. 12, Can. Wildl. Serv., Ottawa. 52 pp.

8. WELLER, M. W., D. L. TRAUGER and G. L. KRAPU. 1969. Breeding birds of the West Mirage Islands, Great Slave Lake, Northwest Territories. Can. Field-Nat. 83:334-360.

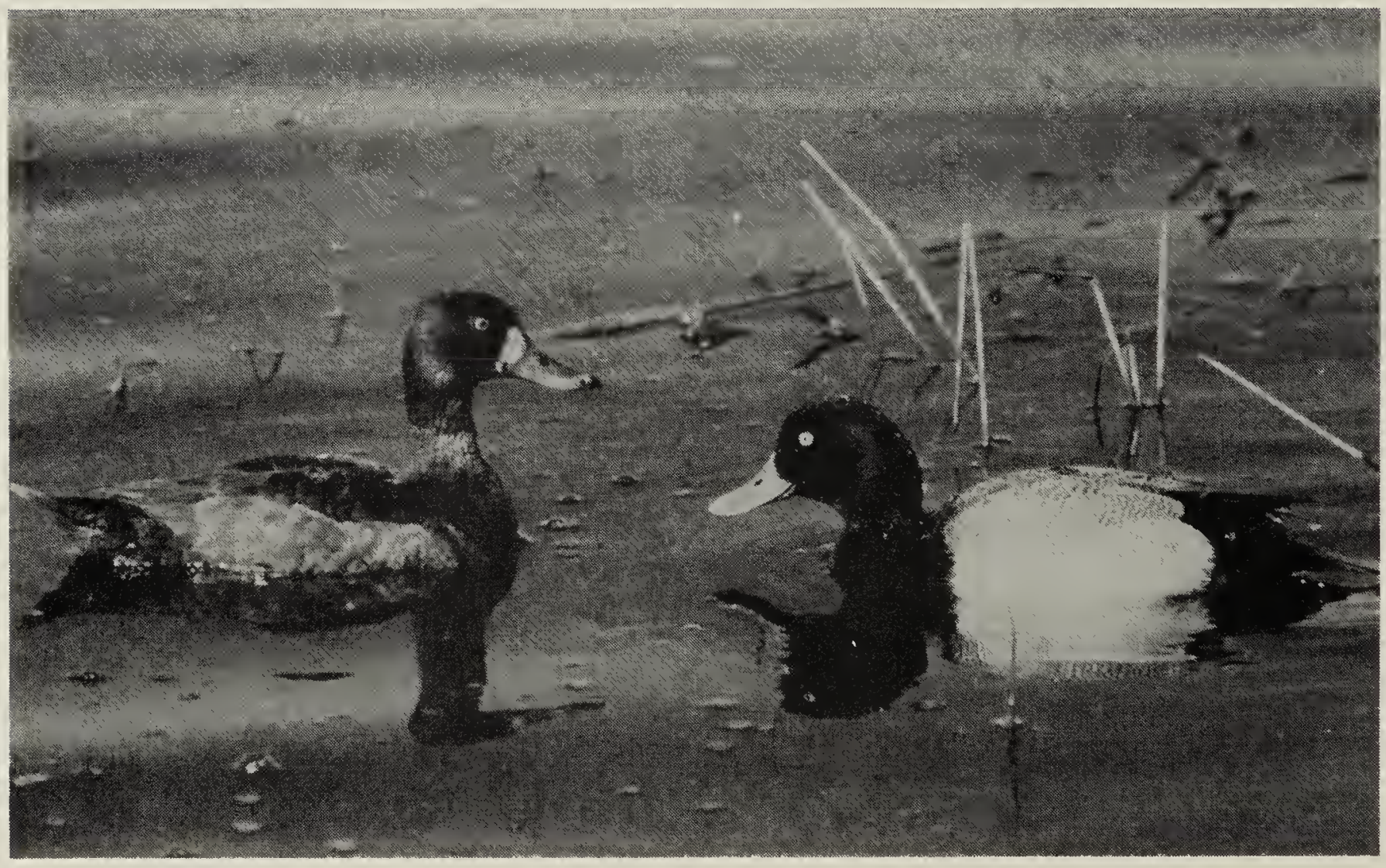

